Article

\title{
Socioeconomic Determinants of Female Development in the Rural North West Province of South Africa
}

\author{
Enioluwa Jonathan Ijatuyi ${ }^{1}{ }^{\circledR}$, Oladimeji Idowu Oladele ${ }^{1}$, Oluremi Adenike Abiolu ${ }^{2}$ \\ and Abiodun Olusola Omotayo ${ }^{1, *(1)}$
}

1 Food Security Niche Area, Faculty of Natural and Agricultural Sciences, North West University, Mafikeng 2745, South Africa; ijatuyienioluwa@gmail.com (E.J.I.); oladele20002001@yahoo.com (O.I.O.)

2 University Library, Federal University of Technology, Akure 340110, Nigeria; ijatuyioa@yahoo.com

* Correspondence: 25301284@nwu.ac.za

Citation: Ijatuyi, E.J.; Oladele, O.I.; Abiolu, O.A.; Omotayo, A.O. Socioeconomic Determinants of Female Development in the Rural North West Province of South Africa. Sustainability 2022, 14, 547. https:// doi.org/10.3390/su14010547

Academic Editors: Samuel Adomako and Albert Danso

Received: 8 October 2021

Accepted: 24 December 2021

Published: 5 January 2022

Publisher's Note: MDPI stays neutral with regard to jurisdictional claims in published maps and institutional affiliations.

Copyright: (C) 2022 by the authors. Licensee MDPI, Basel, Switzerland. This article is an open access article distributed under the terms and conditions of the Creative Commons Attribution (CC BY) license (https:// creativecommons.org/licenses/by/ $4.0 /)$.

\begin{abstract}
Women engagement and reward systems are vital for rural development as they have a direct consequence on the improvement, equality, as well as accelerating agricultural productivity generally, and increasing food supply in particular at the local and national levels. The study highlighted the contribution of the Award Incentives and Competition (AIC) programme in enhancing women farmers' economic strength. It also looked at how influence, change and technological knowhow could improve women farmers' participation in development programmes. It provided an overview of the determinants of female entrepreneurship development in rural North West Province using a quantitative survey method approach. One hundred and fifty-six women farmers, who were randomly selected from all districts in the province and different enterprises out of 520 eligible women farmers, participated in the study. Data were analysed using descriptive statistics and inferential (Probit regression) model. Based on empirical data, the Probit regression model estimates suggested that the educational status, creation of temporary and permanent jobs, and extension sources were some of the determinants of entrepreneurial development in the study area. The study recommends that policymakers continue to advocate for education as female farmers need to participate in development programme(s).
\end{abstract}

Keywords: Awards Incentives and Competition programme; development programme; female farmers; North West Province; socioeconomic determinants; South Africa

\section{Introduction}

Empowerment is a crucial factor in poverty reduction which has been recognized by the World Bank as a prime priority in development aid [1,2]. The role of female entrepreneurs has been intensively studied in socio-economic growth in affluent Western countries. However, the state of entrepreneurship in developing countries remains more vital. As indicated by [1], equality for men and women is a fundamental right, but we have a constant imbalance between men's and women's access and decision-making. Women have fewer economic participation opportunities than men, less access to basic and higher education, higher health and safety costs, and less government representation in many countries. According to [2,3], economic prosperity for women boosts growth and improves economic diversification and income equity in many countries. However, refs. [4,5] mentioned a setback that many African women do not reach their full capacity for economic strength and self-empowerment. Women experience greater inequality, pay disparities, and longer school-to-work transition.

In South Africa, since the enthronement of democracy in 1994, the country has undoubtedly seen a wave of transition, but a favourable environment must be further developed where women will be able to cater for themselves and possibly their children [4]. In a rising democracy, there is a need to start developing powers to women as part and parcel of a recognizable society's capital in South Africa. In so doing, there will be a building of a 
society in which women can choose and are not limited by socio-economic pressures [6]. Consequently, there will be prosperity in homes as the base of the society, and the society in return will improve in economic strength and obviously economies flourish as women actualize empowerment [7]. The inclusion of more women into the workforce will enhance poverty alleviation and economic development in South Africa [8]. Women entrepreneurs are known to use their profit margin to change the standard of living of their families. They also engage more extensively in the schooling of their children to ensure that the poverty chain is disrupted [8].

Several factors influence South African women entrepreneurs: race, location, inequality, lack of land ownership, level of education, size of households, family obligations, and HIV / AIDS [6,7]. Factors including capital access, labour problems, insufficient schooling, training, and sexism have also been described by the Department of Trade and Industry as key constraints affecting the growth and expansion of female entrepreneurial jobs [9-11]. In South Africa, women entrepreneurs remain at the national economic fringe as there are low participation levels of women entrepreneurs in value-adding business opportunities; thus more and more women are taking the route to informal sector entrepreneurship [12].

The government of North West province recognized the continued absence of women from agriculture development, and in 1999 initiated the Awards Incentives and Competition (AIC), in collaboration with the national Department of Agriculture, Fisheries, and Forestry (DAFF) and other main partners [13]. The programme was developed by fostering entrepreneurship trends to promote development through commercialisation among female farmers. With the awards in monetary value and investments in the infrastructure to improve their farming practices, DAFF encourages competitiveness among farmers to accelerate production, jobs, and food security. Women who have enrolled in AIC are presented with a rubric on what the provincial adjudicators are expecting of them, and these rubrics are factors that can lead women subsistent farmers to commercialisation. The current research assesses factors impacting the growth of entrepreneurship in the AIC programme for female farmers. The study also investigated constraints to female entrepreneurship in agriculture in the province and suggested recommendations relating to policy direction to improve the economy of the North West Province of South Africa.

\section{Literature Review}

A variety of literature sources on rural women reveal that this group of individuals participates in development initiatives significantly less than their male counterparts, and their engagement is frequently limited to the implementation stage [11,12]. Women's engagement in rural development is significant because it has the direct consequence of improving equality between men and women, as well as the effects of speeding agricultural development, boosting national productivity, and increasing food supply at the national and local levels [14]. Although South Africa is classified as a middle-income country by the International Monetary Fund (IMF), the great majority of its people remain impoverished [15]. According to the Human Science Research Council, the majority of impoverished people live in rural regions, with the majority of them being women. Women are over-represented among the poor, and their poverty is typically more severe. Women's disproportionate share of poverty indices reflects, in part, the fact that historically, women have had less access to paid work and, within the labour market, tends to have low-paying positions [15].

It may thus be stated that many individuals in rural regions are subjected to poverty, and although some accept their circumstances as they are, others do not accept the difficulties they confront as a given. To the latter, the horrible circumstances in which they find themselves are viewed as a challenge that must be met head-on. These difficulties are frequently met with no aid from the government. Women are frequently in the vanguard of challenging these heinous conditions [15]. Attempts to relieve poverty in rural regions are more difficult for women than men because women not only do so with little or no aid from the government but also with decreasing or no support from their husbands who relocate to metropolitan areas in search of economic possibilities [15]. Traditional beliefs 
about home responsibilities are still prevalent in rural communities. These traditional preconceptions, which frequently place males in higher positions, make women's lives even more difficult [16]. In rural areas, their participation in development programmes and processes is restricted.

According to a study by [16] carried out in North West province, South Africa on determinants and challenges influencing women development, it was noted that the lack of education of participants, lack of remunerations and incentives for a project that started with 22 members and only having three members over a space of time as at the time of her study. Another major constraint identified was absenteeism which was a result of their household commitments, lack of basic infrastructure, and the lack of encouragement from identifying the contributions of participants through award and monetary gifts. However, the women in the community indicated that despite all these inadequacies, women in this project showed determination to deal with their challenges if the government can come to their aid with remunerations monetarily, or in kind.

Over the past decades, women in South Africa have become more active in government and policy-making, with $43 \%$ of the national cabinet and $37 \%$ of parliamentarians being female [11,17]. According to [18,19], small businesses are both a means of entrepreneurship and a source of employment and income. Women entrepreneurs play a significant role in the South African economy by improving welfare, alleviating poverty, and also being a source of wealth and employment creation [11,16]. Women entrepreneurs play a crucial role in people's efforts to meet basic needs and help disadvantaged groups, disabled people and rural families $[18,19]$. South African women have also progressively begun to extend their benefit in the economic sphere by successively managing small and medium enterprises. South African women entrepreneurs engage in subsistence activities, such as vegetable farming, livestock rearing, sewing co-operatives, chicken farming, candlemaking, gardening, and arts and crafts. All these activities that women entrepreneurs engage in are commonly referred to as micro-enterprise projects [14]. Existing studies reveal that private and public sector support for these activities is lacking, exposing women to high risks and poor outcomes [20,21]. Most women entrepreneurs in South Africa play a major role in the social and economic well-being of the rural communities [11,12].

Studies have shown that the South African Government has recognized the value and contributions of women to their communities by giving them support and promoting a change in their attitudes towards the meaning of work [22]. In South Africa, gender inequality remains a big problem. South African women are still having problems being able to have equal rights and advantages as South African men. Literature affirms that women entrepreneurs in South Africa have been excluded from most motivating activities and production factors, such as access to credit, ownership of land, educational opportunities and skills development $[11,12,23,24]$.

Though women may be entrepreneurs in their own rural homes, it is hard for them to branch out and have an actual building from which to run a business. This is because they have problems getting finance to open their own business. Although women entrepreneurs significantly contribute to the success of an economy in various nations of the world, various challenges hinder their entrepreneurial progress. According to [25], entrepreneurial activities in South Africa have shown a gradual decline over the years compared to other developing countries. Ref. [26] stated that South Africa has consistently ranked very poor in the Global Entrepreneurship Monitor survey in terms of entrepreneurial activity. South Africa is not producing a sufficiently entrepreneurial economy and this needs to be addressed to create employment, expand markets, increase production and revitalize communities [26].

Female entrepreneurs are faced with many obstacles that limit their growth and survival [27]. In addition to this, women have to cope with prevailing negative social and cultural attitudes, lack of education and training, as well as gender discrimination [28]. According to [29], even though the small business sector within the Gauteng province provides opportunities for existing entrepreneurs and new venture creation, the question arises as to what barriers, problems, challenges and constraints women entrepreneurs en- 
counter within the province. This study likewise explored the socio-economic determinants of women entrepreneurs within the rural North West province of South Africa and areas in which government and private sector could intervene to assist women entrepreneurs. The study sought to identify the constraints that women entrepreneurs face within the province and suggest possible solutions to minimize these. This research made some recommendations on the study as well.

\section{Theoretical and Conceptual Framework}

Agriculture is the benchmark to the physical and economic survival of human beings; therefore, their reliance on innovation and innovation systems in agricultural development is very vital. For the most part, innovation is seen as a major source of improved productivity and economic growth. Agricultural innovations usually come from the different entrepreneurial stages which include growing, processing, packaging, distribution and consumption of agricultural products. Ref. [30] clarified that the entrepreneur can change or alter the pattern of production by exploiting a development. This may be in ways of employing an untried innovative technique for delivering a new commodity or creating an old one in a new way, opening another wellspring of supply of material or another outlet for items, or organizing a new industry. In agriculture, the entrepreneur requires the existence of technical knowledge to produce new things and the power of disposal over the factors of production in the form of credit.

The concept of entrepreneurship in agriculture could be seen from different angles. Entrepreneurship is a growing force needed for the development and enhancement of any society's economic growth. For this study, agricultural entrepreneurship centres on the theories of innovation which entails growing, processing and distribution; the risk-bearing which speaks to expected profits after investments; the exposure which entails the farming methods; the economic and political growth which speaks to the favourable environment, access to capital as well as the well-being and development of the employees. Therefore, the conceptual framework adopted for this study is based on the theories reviewed as shown in Figure 1. Ref. [31] stated that agricultural entrepreneurs are innovators who must have the technical knowledge and possess the power of disposal over the factors of production.

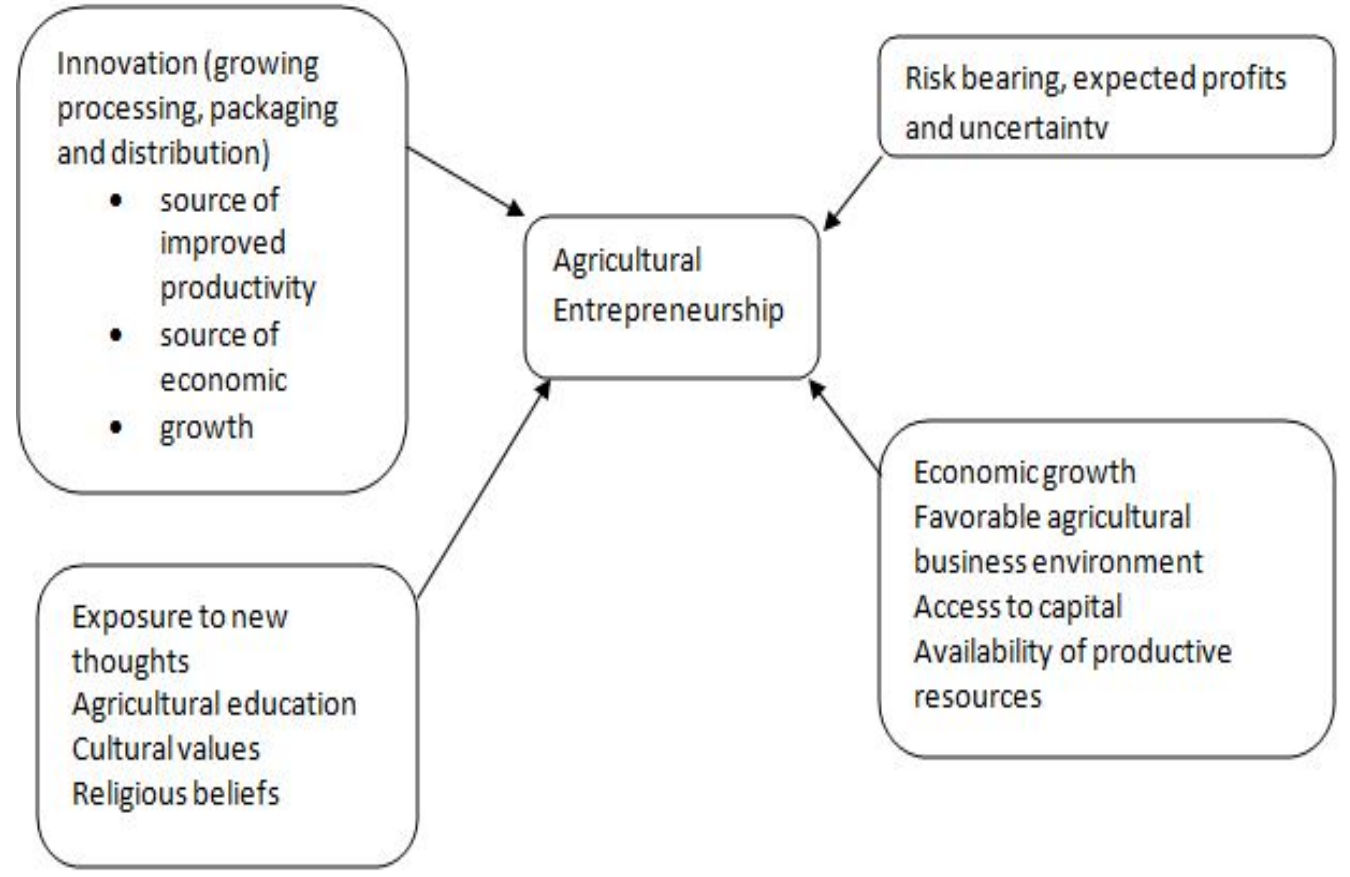

Figure 1. Conceptual framework of the study. 
Ref. [32], expressed that the principal function of the agricultural entrepreneur is to tolerate risk and that production involves various kinds of risks. According to the theory of entrepreneurial development, the route to agricultural entrepreneurial development is through the effective dissemination of technical knowledge and the introduction of an environment favourable to agricultural production.

Exposure to new thoughts and opportunities for creativity and innovation will prompt the making of new ventures in the agricultural sector, and also lift the economic growth of a nation [33]. Exposure and access to education is a vital factor in guaranteeing that farmers, (in particular female farmers) have some level of exposure to resources [34].

The role of the government in the agricultural entrepreneurial process is for the provision of resources and enabling the environment. Ref. [35] proposed that the creation of adequate infrastructure, favourable laws and taxation systems, provision of incentives and subsidies, security to entrepreneurs will encourage people towards agriculture. Governments can likewise build supporting systems for potential entrepreneurs.

\section{Materials and Methods}

\subsection{Study Area}

Surveys were carried out in the province of North West in South Africa (Figure 2). The province's total land area is 106,512 square kilometres, taking up $8.7 \%$ of South Africa's land area and still accounts for 3.2 million population in 2010, amounting to a proportion of $7.1 \%$ of the population of the country [36]. Four districts make up the Province, which are Ngaka Modiri Molema, Bojanala Platinum, Dr. Kenneth Kaunda and Dr. Ruth Segomotsi Mompati with Mahikeng as the capital city. According to the SA-Venues (1999-2015) report, Mahikeng (the capital city) enjoys the same climate around the entire province, with towns in the western areas only slightly hotter and those further south a bit cooler. The average rainfall above 300 to $700 \mathrm{~mm}$ is recorded annually and the summer temperatures range between $22{ }^{\circ} \mathrm{C}$ and $34^{\circ} \mathrm{C}$ during winter months of May to July and this brings with it dry, sunny days and chilly nights and with temperatures ranging from an average of $2{ }^{\circ} \mathrm{C}$ to $20{ }^{\circ} \mathrm{C}$ in a single day.

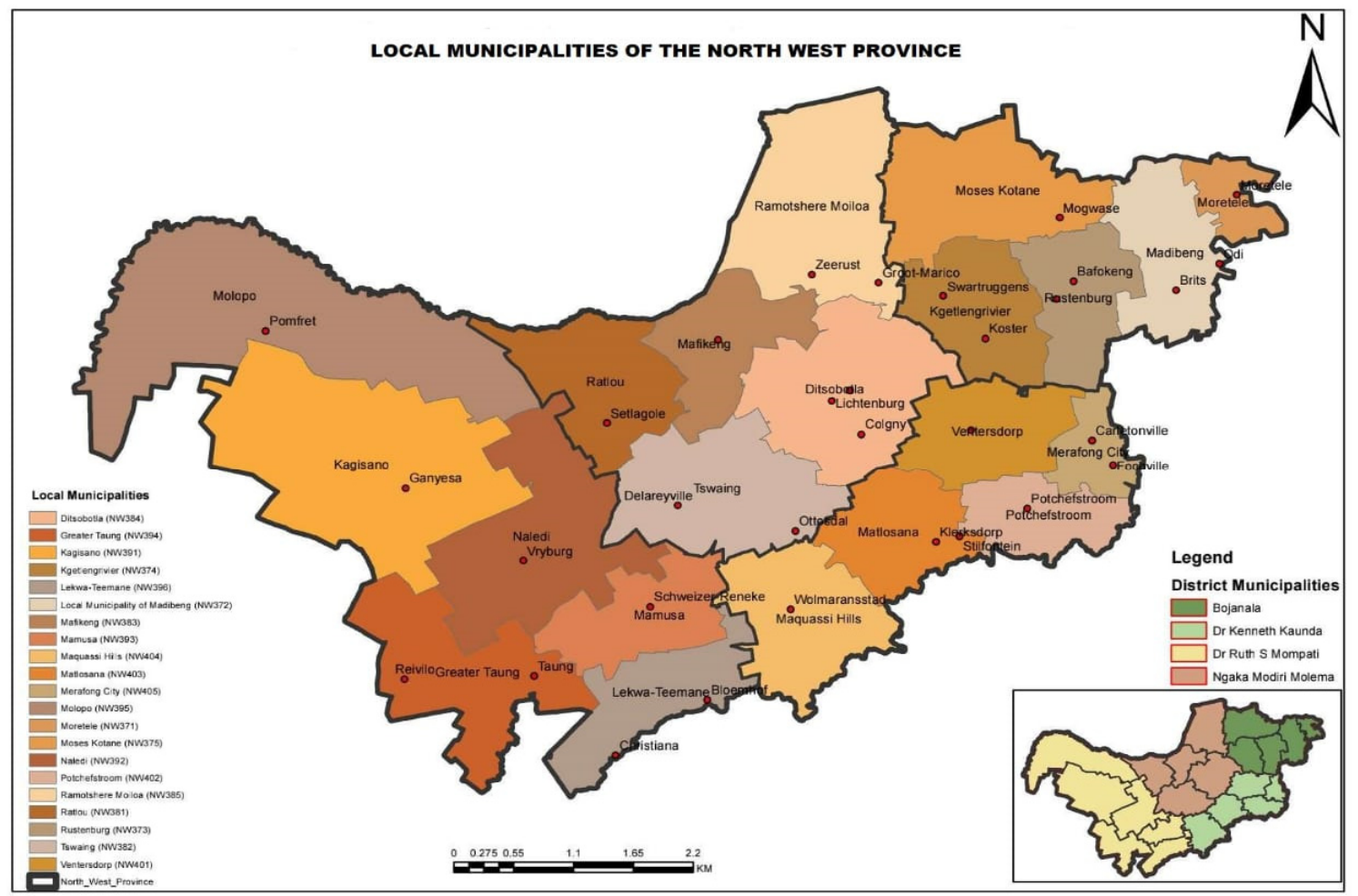

Figure 2. Map of the identified districts for the study. 
Most of the Bojanala Platinum district and some parts of the central and southern districts of the North West Province have mixed Bushveld vegetation. This vegetation consists of a more open acacia savannah with tall dense grass veld, including edible trees and shrubs, which provide browse, and grazing. However, a variety of grasses in this vegetation provides limited grazing value [11]. The Dr. Ruth Segomotsi Mompati district is dominated by Kalahari thornveld and shrub bushveld. The vegetation is of acacia savannah type in which the common trees are camel thorn (Acacia Giraffe) and karee thorn (Hycium Oxyladium) [37]. The province is known as the "Texas of South Africa" because it produces the largest beef with Hereford cattle being the most popular. North West Province is well known for cattle farming, especially at Stella-land near Vryburg, while the areas around Rustenburg and Brits are fertile, mixed-crop farming land. The Province is the major producer of white maize in the country, with sunflower and peanuts being the other most important crops produced in the Province [37].

\subsection{Sample Size and Selection}

The study employed a simple random sampling, a quantitative method, and a descriptive design for the research. A simple random sampling is defined as one in which every unit in the population has a chance $(0<X<1)$ of being selected in the sample which can be accurately determined. The study focused on Ngaka Modiri Molema, Dr. Ruth Segomotsi Mompati, Dr. Kenneth Kaunda and Bojanala Platinum districts. Female respondents randomly selected from each district comprised eighty-one (81) from Ngaka Modiri Molema townships and villages, 30 from Dr. Ruth Segomotsi Mompati townships and villages, 16 from Dr. Kenneth Kaunda townships and villages, and 29 from Bojanala Platinum district townships and villages. The exact number of the total female farmers of the programme in each district could not be ascertained at the time of data collection, however, a sample size of 156 women agreed to take the study out of 520 women in the development programme [11].

The formula for the determination of sample size by [38,39] was used in the study as follows:

$$
S=x^{2} N P(1-P) \div e^{2}(N-1)+x^{2} P(1-P)
$$

where $S=$ sample size, $N=$ population size, $e=$ acceptable sampling error, $x^{2}=$ chi-square of degree and confidence $95 \%=3.841$, and $P=$ proportion of population (if unknown 0.5 ).

The instrument used for data collection was a structured questionnaire consisting of sections A to F. Section A focused on the demographic characteristics of the respondents, $\mathrm{B}$ was on their entrepreneurial activities, $\mathrm{C}$ was on their level of participation in the AIC programme while D elicited information on respondents' benefits from AIC and section E elicited information on the constraints they faced and F delved into production costs and returns. The questions consisted of 3-point Likert scale type, closed and open-ended ones. A board of experts from the Department of Agricultural Economics and Extension of the North West University, Mahikeng carried out the face validity of the instrument while its reliability was pre-tested on 10 female entrepreneurs in Kenneth Kaunda District but these were not part of the final study participants. A split-half analysis was used to test the instrument's reliability and this generated a co-efficient of $R=0.81$. Figure 2 is the map of the study area showing the districts.

\subsection{Model Specification}

\subsubsection{Descriptive Statistics}

Descriptive statistics are a technique used to depict a sample's attributes. Descriptive instruments, such as percentage and frequency tables were employed in the study. Descriptive statistics were employed for the specific objectives, including those focusing on the socioeconomic characteristics of the respondents, the degree of activity of participants in AIC as well as the distribution into the degree of activity of AIC. The pooled scores from the enterprises generated the household commercialisation index, which was later used 
as a proxy for entrepreneurship development for each of the female farmers participating in AIC.

\subsubsection{Inferential Statistics}

In the study, the probit regression model is used because it is the standard method for estimating binary category dependent variables following [40]. The dependent variable was the development of entrepreneurship based on the commercialisation index created. For the inferential statistical, data were analysed using the IBM Social Sciences Statistical Packages (SPSS) and STATA. Entrepreneurship development was categorized between lowand high commercialisation, where low was coded (0) and (1) for high development. The Probit econometric model explains only the probabilities of independent variables on a non-continuous dependent variable [41]. The Probit model for the study is shown below:

$$
\begin{gathered}
Z_{j}=\alpha+\beta_{j} \sum_{i=1}^{n} I_{j}+E_{j} \\
Z_{j}=\alpha_{0}+\alpha_{1} \times 1+\alpha_{2} X_{2}+\alpha_{3} X_{3}+\alpha_{4} X_{4}+\alpha_{5} X_{5}+\alpha_{6} X_{6}+\alpha_{7} X_{7}+\ldots+e
\end{gathered}
$$

where $Z_{j}$ is the binary dependent variable indicating the level of participation in the AIC; (0) if the respondent is regularly, (1) if occasionally. $\alpha$ and $\beta_{j}$ are the parameters of the estimates. $N=$ number variables, $E_{j}=$ Error term, $I_{j}=$ the measurement of the independent variables is specified as age, marital status, educational status, farm size, land ownership, income level, extension visit, extension source, and membership of the cooperative society. Table 1 shows the variables fitted in the model.

Table 1. Variables fitted in the model.

\begin{tabular}{cc}
\hline Variable & Description \\
\hline Educational status & $\begin{array}{c}\text { Number of years of academic } \\
\text { education } \\
\text { Farm size }\end{array}$ \\
Farmland & Dummy $(0,1)$ \\
Income level & Dontinuous \\
Extension visit & Continuous (Actual amount in Rands) \\
Extension source & Dummy $(0,1)$ \\
Membership of cooperative & Continuous (Ticked type of extension source(s)) \\
Involvement in land ownership, & Dummy $(0,1)$ \\
administration and decision making & Dummy $(0,1)$ \\
Access to all relevant documentation & Dummy $(0,1)$ \\
Involvement in the adjudication & Dummy $(0,1)$ \\
process & Dummy $(0,1)$ \\
Responsible use of farming inputs & Dummy 0,1$)$ \\
Improved farming methods & Dummy $(0,1)$ \\
Bookkeeping & Dummy $(0,1)$ \\
Lack of infrastructural growth & Dummy $(0,1)$ \\
Welfare and creation of temporary jobs & Dummy $(0,1)$ \\
Contribution to employee wellbeing &
\end{tabular}

\subsection{Ethical Approval}

The ethical approval to carry out this study was given by the North West University through the Faculty of Natural and Agricultural Sciences with certificate number NWU-00516-18-A9. Anonymity was ensured through informed consent that was explained in the details clearly to the respondents. Their willingness to participate was formally gotten through verbal consent and appending their signatures on a consent form that was provided. 


\section{Results and Discussion}

\subsection{The Socio-Economic Characteristics of the Rural Women}

Table 2 display the socioeconomic profiles of the respondents. The findings revealed that interviewees were still in an active year as the mean age was found to be 46 years. This is corroborated by [42], who identified the women were between 40 and 49 years in a related survey. About half (54.5\%) were married. This will have a positive effect on the productivity and well-being of the respondents as new family members can contribute to their jobs. The result is also consistent with [43], who emphasized that in a related survey the majority of respondents listed their marital status.

Table 2. Socioeconomic characteristics of the respondents.

\begin{tabular}{|c|c|c|}
\hline Variable & Frequency & Percentage \\
\hline \multicolumn{3}{|l|}{ Age (Years) } \\
\hline $21-30$ & 9 & 5.8 \\
\hline $31-40$ & 32 & 20.5 \\
\hline $41-50$ & 47 & 30.1 \\
\hline $61-70$ & 28 & 17.9 \\
\hline \multicolumn{3}{|l|}{ Marital status } \\
\hline Married & 85 & 54.5 \\
\hline Single & 51 & 32.7 \\
\hline Divorced & 8 & 5.1 \\
\hline Widow(ed) & 12 & 7.7 \\
\hline \multicolumn{3}{|l|}{ Educational status } \\
\hline Standard & 23 & 14.7 \\
\hline Matric & 71 & 45.5 \\
\hline Diploma & 38 & 24.4 \\
\hline Degree & 23 & 14.7 \\
\hline None & 1 & 0.6 \\
\hline \multicolumn{3}{|l|}{ Farm size (Hectares) } \\
\hline $1-500$ & 143 & 92.3 \\
\hline 501-1000 & 6 & 3.9 \\
\hline 1001-1500 & 5 & 3.2 \\
\hline $1501-2000$ & 1 & 1.9 \\
\hline \multicolumn{3}{|l|}{ Land ownership } \\
\hline Yes & 62 & 39.7 \\
\hline No & 94 & 60.3 \\
\hline \multicolumn{3}{|l|}{ Income level (Rand) } \\
\hline $1-500,000$ & 152 & 97.4 \\
\hline $5,000,001-1,000,000$ & 2 & 1.4 \\
\hline $1,500,001-2,000,000$ & 1 & 0.6 \\
\hline $5,500,001-6,000,000$ & 1 & 0.6 \\
\hline \multicolumn{3}{|l|}{ Extension visit } \\
\hline Yes & 123 & 78.8 \\
\hline No & 33 & 21.2 \\
\hline \multicolumn{3}{|l|}{ Extension source } \\
\hline Colleagues & 17 & 10.9 \\
\hline Friends & 28 & 18.0 \\
\hline Relatives & 35 & 22.4 \\
\hline Extension agents & 57 & 36.5 \\
\hline Radio & 1 & 0.6 \\
\hline Television & 4 & 2.6 \\
\hline Other sources & 14 & 9.0 \\
\hline
\end{tabular}


Table 2. Cont.

\begin{tabular}{ccc}
\hline Variable & Frequency & Percentage \\
\hline Cooperative membership & & \\
\hline Yes & 77 & 49.4 \\
No & 79 & 50.6 \\
\hline Total & 156 & 100 \\
\hline
\end{tabular}

The level of the importance of education in agriculture cannot be overemphasized. The basic form of education (high school/matric) regarding the respondents $(45.5 \%)$ as literates enough to make decisions was highlighted. This agrees with [42], who recorded that most of their respondents only completed their matriculation. These findings agree with [36] that found out that farmers who have passed standard five are regarded as literate enough to make decisions about production and the requirement of agriculture.

In terms of the farm-size of the respondents, the findings revealed that the majority (92.3\%) had between 1 and 500 hectares of land which they used for farming. The average size of the farm was 150 hectares. The outcome is consistent with [44] who, in a related survey in the province of Gauteng, found the average farm size to be 93.8 hectares.

With respect to land as a property on which respondents farmed, the study found that $60.3 \%$ did not possess ownership. This suggests that land possession can be a barrier to improved production for these respondents. Ref. [41] mentioned that the key constraints for farmers in developing countries are land, credits, extension education, and sufficient technology. The findings on annual sales indicated that $97.4 \%$ had less than ZAR 500,000 in annual revenues. The total sales each year were less than ZAR 500,000.

Extension service was found to have been appreciated by the majority $(78.8 \%)$ and $21.2 \%$ did not have any extension interaction. This access to extension facilities for the majority of respondents is a positive sign of updated information. The conclusions are confirmed by [45] that agricultural extension has been the tool to improve agriculture and quality of life in rural areas worldwide. Ref. [45] indicated that the extension of agriculture is often emphasized as "crucial to agricultural development, poverty reduction, and food safety by development experts."

The primary source by which respondents obtained information was extension officers $(36.5 \%)$. Findings also revealed that about half $(50.6 \%)$ of the respondents were not affiliated with a cooperative organisation as well.

\subsection{Degree of Activity for Award, Incentives, and Competition}

The data in Table 3 indicate the distribution of the respondents to the degree of AIC operation. Some statements were given to respondents based on their involvement in the participation in the programme. They were requested to indicate their degree of activity for AIC. Eighty-two percent of the respondents reported that they were able to create temporary and permanent employment regularly and this ranked first with a score of 1.27 among all the activities. This outcome agrees with [45] who said that the female entrepreneur currently has 15 permanent jobs and at least 30 contract jobs for her farmworkers to contribute to the regional economic development and employment goal, which has been given an award in the province. Ref. [46] reported that female entrepreneurs in the North West province are doing a strong job in developing temporary and permanent employment.

Ranking second to this, $78.2 \%$ reported contributing to the well-being of their workers daily showing a mean score of 1.33 . Improving the standard of living of staff members is paramount as an entrepreneur. Ref. [47] claimed that high-potential female entrepreneurs improve their economic well-being by generating jobs, goods and services, cross-border trading, and enhancing the socio-economic fabric of society. 
Table 3. Respondents' distribution into the degree of activity for award, incentives, and competition.

\begin{tabular}{|c|c|c|c|c|c|}
\hline \multirow{2}{*}{$\begin{array}{l}\text { Statement Activity for } \\
\text { Participants in AIC }\end{array}$} & \multicolumn{3}{|c|}{ Frequency (\%) } & \multirow{2}{*}{\multicolumn{2}{|c|}{ Mean Score Rank }} \\
\hline & Regularly & Occasionally & Rarely & & \\
\hline $\begin{array}{l}\text { Involvement in the ownership, } \\
\text { management, and decision-making } \\
\text { aspects of the entity }\end{array}$ & $103(66.0)$ & $34(21.8)$ & 19(12.2) & 1.46 & 7th \\
\hline $\begin{array}{l}\text { Access to all relevant documents for } \\
\text { verification process }\end{array}$ & $83(53.2)$ & $43(27.6)$ & $30(19.2)$ & 1.66 & 8th \\
\hline $\begin{array}{l}\text { Willing to be interviewed at all } \\
\text { adjudication process }\end{array}$ & $81(51.9)$ & $44(28.2)$ & 31(19.9) & 1.68 & 9th \\
\hline $\begin{array}{l}\text { Demonstrate responsible use of } \\
\text { production inputs, such as } \\
\text { pesticides, fertilizers, and vaccines }\end{array}$ & 104(66.7) & $38(24.3)$ & $14(9.0)$ & 1.42 & 5 th \\
\hline $\begin{array}{l}\text { Demonstrates an understanding of } \\
\text { improved farming methods }\end{array}$ & $111(71.2)$ & 27(17.3) & $18(11.5)$ & 1.40 & 4th \\
\hline $\begin{array}{l}\text { Demonstrating a good sense of } \\
\text { financial management } \\
\text { and bookkeeping }\end{array}$ & 104(66.7) & $37(23.7)$ & $15(9.6)$ & 1.43 & 6th \\
\hline Produce is sold & & & & & \\
\hline $\begin{array}{l}\text { locally/internationally to enhance } \\
\text { economic growth }\end{array}$ & $119(76.3)$ & $21(13.4)$ & $16(10.3)$ & 1.34 & $3 r d$ \\
\hline $\begin{array}{l}\text { Creation of temporary and } \\
\text { permanent jobs }\end{array}$ & $128(82.0)$ & $14(9.0)$ & $14(9.0)$ & 1.27 & 1 st \\
\hline $\begin{array}{l}\text { Contribution to employee } \\
\text { well-being and development }\end{array}$ & $122(78.2)$ & $17(10.9)$ & 17(10.9) & 1.33 & 2nd \\
\hline Total & $156(100)$ & & & & \\
\hline
\end{tabular}

The research has also shown that $76.3 \%$ sold the produce from their firms locally/internationally on a regular basis, and with a mean score of 1.34 ranked third to consistently raise economic activity in their community. This is not consistent with [6] who found that respondents had no local markets in a similar study in King William's Eastern Cape Town because they were informed that their crops were not compliant with the local market expectations and criteria and that they lack certificate for good farm practices. The findings of the analysis, however, agree with [48] that respondents in the East Hararghe district sold their goods locally in various commercial centres; most (70\%) of whom were resident wholesalers, retailers customers.

It was also seen that a majority $(71.2 \%)$ consistently showed an appreciable improvement in their agricultural practices, this ranked fourth with a mean score of 1.40. This finding is consistent with those [49] that a majority of women in the South African Province of KwaZulu-Natal developed their mixing and pesticide application methods including handbag pesticides equipment from buckets and brooms.

This study also found that the majority $(66.7 \%)$ displayed good agricultural production input practices in their application of pesticides, fertilizers, and vaccines having a mean score of 1.42 ranked fifth. Ref. [50] discussed that water contamination caused by unsustainable activities could be calamitous significant risks for human health and the ecology of the earth; a concern frequently understated by government leaders as well as the farmers and though in some circles, it is seemingly reported that agriculture today is the main source of water pollution since agriculture accounts for the biggest discharge of agrochemical, herbal, and other items. As a result, ref. [50] further claimed that in farming, animals are the only major producers of wastewater and excreta by volume more than human beings. Ranking sixth with a mean score of 1.43 is the fact that a large proportion $(66.7 \%)$ demonstrated good accounting practices regularly in the management of their finances as well as keeping good records with respect to their entrepreneurial activities. This is consistent with [51], which highlighted that the best way to show financial success and the correct direction is by applying proper financial accounting and bookkeeping standards. Furthermore, ref. [51] stated that today's farmers should be thoroughly familiar 
with the numerous management functions, regardless of the size of the farm business. Although all the management functions are important, it is the financial management of the farm business that brings everything together. Financial development and monitoring of agricultural operations will provide the farmer with a summary of the full farm sector, which will, in turn, contribute to better-informed business decisions. Prudent financial management not only links every part of the agricultural sector but also "oils the wheels," which makes the business more successful. Farmers must also be financial managers; to ensure that farm statistics are reliable and a proven record-keeping mechanism is developed and preserved.

The majority (66\%) reported that they also were consistently involved in the company's ownership, management, and decision-making aspects and this attracted a mean score of 1.46 ranking seventh and with a mean score of 1.66 and ranking eighth is the fact that about half of respondents (53.2\%) indicated that they had access to relevant records and documents for verification whereas a slightly lower percentage of respondents, that is, $51.9 \%$ showed their willingness to surrender themselves to interviews in any adjudication process; this is, however, the last of the statement and its mean score is 1.68. It should be noted that a very small percentage was shown in all the other frequency levels, such as "occasionally" and "rarely".

\subsection{Probit Regression Analysis of the Determinants of the Respondent's Participation in AIC}

The probit regression analysis of the socioeconomic characteristics of the respondents and their participation in AIC displayed in Table 4 shows that socioeconomic characteristics have some effects on development programmes. The findings of the analysis agree with [52], who established that the respondents' socio-economic characteristics strongly affect development programme participation.

Table 4. Relationship between respondent's socioeconomic characteristics and participation in AIC.

\begin{tabular}{lcccccc}
\hline Variables & Coef. & Std. Err. & $\mathbf{Z}$ & $\mathbf{P}>\mathbf{~ z ~} \mathbf{l}$ & $\mathbf{V I F}$ & Eigenvalue \\
\hline Edustatus & -0.2791797 & 0.1559196 & -1.79 & 0.073 & 1.24 & 1.1360 \\
Farm size & -0.0014574 & 0.0005722 & -2.55 & 0.011 & 1.26 & 0.8678 \\
Farmland & -0.3384704 & 0.1328096 & -2.55 & 0.011 & 1.27 & 0.4763 \\
Incomelevl & $-3.74 \times 10^{-6}$ & $1.40 \times 10^{-6}$ & -2.66 & 0.008 & 1.18 & 0.4233 \\
Extnsvisit & 1.279305 & 0.4100504 & 3.12 & 0.002 & 1.35 & 0.2915 \\
Extnsource & 0.3971631 & 0.1217477 & 3.26 & 0.001 & 1.33 & 0.2131 \\
Mbrcoopratv & 0.7569617 & 0.3159512 & 2.40 & 0.017 & 1.28 & 0.1632 \\
Invleinownsp & 0.2135855 & 0.2779829 & 0.77 & 0.442 & 2.06 & 0.1125 \\
Accreldoc & 1.048796 & 0.4318778 & 2.43 & 0.015 & 3.85 & 0.1037 \\
Intvadjproc & -0.8867397 & 0.395289 & -2.24 & 0.025 & 3.66 & 0.0944 \\
Rspnbuse & 0.9328082 & 0.3818567 & 2.44 & 0.015 & 2.78 & 0.0802 \\
Imprvfarmmtd & -0.2407078 & 0.3580697 & -0.67 & 0.501 & 2.66 & 0.0698 \\
Bookkeep & 0.8318066 & 0.2999474 & 2.77 & 0.006 & 1.84 & 0.0550 \\
Lclintecgrwt & -0.7077047 & 0.3964738 & -1.78 & 0.074 & 3.09 & 0.0486 \\
Temperjob & -0.8136516 & 0.4983845 & -1.63 & 0.103 & 3.71 & 0.0362 \\
Empwellbng & 0.9734428 & 0.413269 & 2.36 & 0.018 & 33.26 & 0.0237 \\
_cons & -4.091537 & 0.9772626 & -4.19 & 0.000 & -6.006937 & -2.176138 \\
Mean VIF & & & & & 2.22 & \\
\hline
\end{tabular}

Edustatus = Educational status, Farmsize = Farmsize, Farmland = Farming land, Incomelevel = Income level Extnsvisit $=$ Extension visit, Extnsource $=$ Extension source, Mbrcoopratv $=$ Membership of a copperative society Invleinownsp $=$ Involvement in administrative and decision making process, Accreldoc $=$ Access to all relevant documentation, Intvadjproc $=$ Interview during adjudication process, Imprvfarmmtd = Improvement in farming methods, Bookkeep = Improvement in accounting and bookkeeping, Lclintecgrwt = Lack of international and local market growth, Temperjob = creation of more temporary jobs, Empwellbng = Improvement of employee wellbeing.

In comparison, the educational level of respondents at $10 \%(p \leq 0.10)$ was negative. This means that the schooling level of the respondent declines, contributing to a $10 \%$ decline in the AIC programme in the field of study. Refs. [53,54] stated that education is one of the main factors that enhance farmers' ability to grasp simple farm management, financial 
management, agricultural marketing concepts, and business networking skills. In other words, the quality of education will increase the farmer's productivity in producing agricultural income. Additionally, this finding corroborates [55] who found that respondents' educational level was important to productivity in a related study. In addition, ref. [56] also made observations that the level of education influences the level of participation in development programmes.

The size of the farmland was negatively significant at $5 \%$ to the level of participation. This means that with the farm size of participants declining, the level of participation by respondents in the AIC programme would decrease by 5\%. The result disagrees with [53] in Limpopo province that the coefficient of the farm size has a favourable effect on respondents farm incomes. The profits of a farmer would increase tremendously with the availability of a greater farm size, which is used for production. Ref. [57] revealed that farmers with more than two hectares had greater income than farmers of less than two hectares with average sizes of land.

The significance of farmland to the participation of the respondents in the AIC programme was negative at a $5 \%(p \leq 0.05)$ level. This implies that a $5 \%$ decrease in the farmland will also decrease the idea of the respondent participating in AIC. When farmers are confronted with the high rent to pay on a land lease, communal farm lease, it will discourage farmers to participate in the scheme. This result does not agree with [44], who did not find the variable farmland significant to the study conducted in Gauteng, South Africa.

The income level as a variable was found to be negatively significant at a $1 \%(p \leq 0.01)$ level. This means that a unit decrease in the income level of the respondents will lead to a unit decrease in the participation of respondents in the AIC programme in the study area. The result agrees with the finding of $[55,56,58]$, who all found that income was also a significant predictor of the level of participation in this context, and that income influences the level of participation in a programme of development.

Extension visit as a variable was found to be positively significant at a $1 \%(p \leq 0.01)$ level. This result means that a unit increase in the access to extension by respondents will increase their participation in AIC. The finding corresponds with [59], who also found that access to extension services in their study increased participation in the market. Furthermore, they identified that regular contact with extension agents will keep farmers updated with information regarding a healthy market, new and improved technologies, and so on. As an important relevant input of production, ref. [60] indicated that the demand for extension knowledge, like any other input into a standard production function, stems from the underlying demand for farm output based on profiteering behaviour. In essence, the need for extension information is related to the cost of extension contacts, with other input costs remaining unchanged. However, ref. [61] discovered that, as it is presently developed, public extension assistance programmes are not structured to address the needs of the capital-poor smallholder farmers and argue that the system needed change to help smallholder farmers break free from their dependence and poverty.

The variable extension source was found to be positively significant to participation in AIC at a $1 \%(p \leq 0.01)$ level. This means that a unit increase in the use of the source of extension service delivery to respondents will lead also to an increase in participation in the AIC programme in the study area. In line with this, the study found that most of the respondents had access to extension services which they obtained mainly through the extension agents. According to [62], the extension agents remain the key sources of knowledge on the agricultural market in rural households, and communications with extension agents keep farmers up-to-date on market sites, markets, and prospective buyers and/or sellers.

In addition to the above, membership of a cooperative society was found to be positively significant to AIC participation at a 5\% $(p \leq 0.05)$ level. This means that being a member of a cooperative society gives about a $5 \%$ chance of farmers to participate in AIC in the study area. This result disagrees with [60], who found out that membership of a cooperative society was insignificant in the market participation. This implies that membership of 
a cooperative society played a less significant role as a channel of information exchange and also in encouraging one another to participate in government-funded schemes. This is consistent with [63] who, in a similar study also found the membership in a cooperative society influences the participation of respondents in a development programme.

At a $5 \%(p \leq 0.05)$ access to all the related authentication records was positive. This means that the provision of all the paperwork of the farmer and the entity during the verification process to the authority and a swift response from designated authorities encourages participation in the study area by $5 \%$. In addition, the ability to be interviewed during every adjudication process was found to be negative. This means a decrease in the willingness of respondents to be interviewed will lead to a decrease in the participation of farmers in the AIC programme in the study area.

The Demonstration of responsible use of inputs, such as pesticides, fertilizers, and vaccinations was positive at the level of $5 \%(p \leq 0.05)$ for the participants in the study area. This means that for every use of the production input, there is a $5 \%$ increase in participation in the AIC development programme. According to [41], intensive usage of inputs, such as pesticides and organic fertilizers has become the primary means of achieving growth in crop output and this might serve as a motivating factor for a person to participate in development programmes. However, crops and livestock are the main agricultural pollution sources; aquaculture is also emerging as a source, the responsible use of agricultural production inputs assists in reducing the menace of agricultural pollutions, contaminations from settlements and industries as degradation of inland and coastal waters.

The evidence of a strong sense of financial accounting and bookkeeping was obvious at a $1 \%(p \leq 0.01)$ level. This result implies that as respondents record a unit increase in the book-keeping and the financial management of the enterprise, the more they participate in the AIC development programme. It is expected that as an entrepreneur, one should have a fairly good knowledge of accounting principles and procedures.

Selling the produce of the entity locally/internationally to enhance economic growth was negatively significant to participation in AIC in the study area at a $10 \%(p \leq 0.10)$ level. This indicates that a $10 \%$ decrease in the farmer's access to either local or international markets will decrease their participation in the AIC development programme in the study area. Access to the market will contribute to the economic growth of the locality and the community where the farmer is located through the provision of good farm produce for people to buy and eat in which generation of wealth and riches is achieved by the farmer. The finding of the study is in disharmony with [64], who opined that in terms of agricultural exports' role in economic growth, the agricultural sector did not play a growth-leading role because it did not meet the criteria required for it to do so. Ref. [6] also reported that respondents from their study also sold to informal markets with a low market value in Eastern Cape, King William's Town.

The contribution to the welfare and development of workers was found to be positively significant for female farmers' involvement in the AIC at a $5 \%$ level $(p \leq 0.05)$. As farmers contribute nearly $5 \%$ to their employees' well-being, they will be more involved in the AIC growth programme. The result agrees with [65-68] who also noted that the welfare and growth of workers are mandatory, as one of the imperatives for the green agricultural economy.

The marginal effect of the variables using the variance inflation factor (VIF) was employed to test for multicollinearity for the variables giving a mean VIF of 2.22. A strong tolerance for the variables measured suggests that the study demonstrates no noticeable multicollinearity.

\section{Conclusions}

The degree of respondents' participation in the activities of development programmes showed that education of respondents, creating temporary and permanent jobs, employee well-being and development, and extension sources are major factors that should be 
encouraged among entrepreneurs in the study area, in order to better contribute to the economic development and welfare of their communities and households respectively.

The responsible use of production inputs (pesticides and fertilizers) indicated a significant contribution to the participation of respondents in development programmes and as such, should be encouraged as this is also environmentally healthy. The probit regression model shows the different effects of socioeconomic characteristics of respondents and their participation in AIC programmes. The demonstration of a strong sense of financial management and bookkeeping are both important at different levels of agricultural accountability. This means that significantly positive factors promote participants' involvement in the development programme at different commercialisation stages.

\section{Recommendations}

The study recommends that:

1. Policymakers should continue to advocate for enhanced education as female farmers need to participate in development programme(s);

2. Younger generations of women should be encouraged into agriculture;

3. There should be the establishment of cooperative societies as this encourages female farmers to participate in development programmes;

4. More incentives should be provided to assist the respondents with the re-payment of their lease, as the majority did not own their farmland. A decrease in the farm sizes will lead to a decrease in participation in the development programme;

5. Access to timely extension services through extension agents should be provided as it has a significant impact on production as well as participating in the development programme;

6. The responsible use of farming inputs should be encouraged among farmers to avoid contamination and pollution of water;

7. Responsible accounting attitude and basic financial management and book-keeping should be encouraged and sustained among farmers.

Author Contributions: E.J.I. designed and carried out the survey, O.I.O. and A.O.O. derived the models and analysed the data. O.A.A. assisted with the measurements and interpretation of the data analysis. All authors have read and agreed to the published version of the manuscript.

Funding: This reserach recieved no external funding. The APC was funded by the North West Unievrsity, Mafikeng campus, South Africa.

Institutional Review Board Statement: The ethical approval to carry out this study was given by the North West University through the Faculty of Natural and Agricultural Sciences with certificate number NWU-00516-18-A9.

Informed Consent Statement: Anonymity was ensured through informed consent that was explained in the details clearly to the respondents. Their willingness to participate was formally gotten through verbal consent and appending their signatures on a consent form that was provided.

Data Availability Statement: The data will be provided on reasonable request from the first author of the study.

Acknowledgments: We would like to acknowledge the support of stakeholders including all participants with their informed consent that contributed to the success of this paper. Additionally, the provision of the enabling environment for the first author's PhD research as well as the financial support of the North West University on the article processing charge (APC) is duly acknowledged.

Conflicts of Interest: The author(s) declare that we have no financial or personal relationship(s) that may have inappropriately influenced us in writing this article. The views and opinions expressed in this article are those of the authors and do not necessarily reflect the official policy or position of any affiliated agency of the authors. 


\section{References}

1. Unidas, N. Facts and Figures: Economic Empowerment. UN Women. 2015. Available online: https://www.unwomen.org/en/ what-we-do/economic-empowerment/facts-and-figures (accessed on 6 September 2021).

2. IMF Pursuing Women's Economic Empowerment. Policy Pap. 2018, 18, 1.

3. Bexell, M. Global Governance, Gains and Gender. Int. Fem. J. Politics 2012, 14, 389-407. [CrossRef]

4. Ezenwa-Onuaku, C. Gender Parity Gaps and Poverty: Empowering African Women for No Poverty and Zero Hunger. In Empowering African Women for Sustainable Development; Palgrave Macmillan, Cham: London, UK, 2020; pp. 23-38.

5. Adeola, O. Introduction: Empowering African Women-Towards Achieving the UN's 2030 Sustainable Development Goals. In Empowering African Women for Sustainable Development; Palgrave Macmillan, Cham: London, UK, 2020; pp. 1-10.

6. Khapayi, M.; Celliers, P.R. Factors limiting and preventing emerging farmers to progress to commercial agricultural farming in the King William's Town area of the Eastern Cape Province, South Africa. S. Afr. J. Agric. Ext. 2016, 44, 25-41. [CrossRef]

7. Mojapelo, J.T.; Faku, M.E. Bridging the Gender Gap and Promoting Representation of Women in the National Parliament: A Comparative Analysis Study of South Africa and Lesotho. Gend. Quest. 2020, 7, 1-15. [CrossRef]

8. Ijatuyi, E.J.; Oladele, O.I.; Omotayo, A.O. Effects of award incentives and competition on entrepreneurship development of women farmers in North West province, South Africa. Afr. J. Sci. Technol. Innov. Dev. 2020, 1-8. [CrossRef]

9. Kabeer, N. Gender, Livelihood Capabilities and Women's Economic Empowerment: Reviewing Evidence over the Life Course. Available online: eprints.Ise.ac.uk/90462/ (accessed on 2 February 2020).

10. Alemu, D. Women's socio-economic empowerment and uptake of HIV testing in Ethiopia. Ph.D. Thesis, University of South Carolina, Columbia, SC, USA, 2020.

11. READ Annual Report for 2014/15 Financial Year Vote 13: Department of Rural, Environment and Agricultural Development Province of the North West. Available online: https:/ / provincialgovernment.co.za/department_annual/351/2015-north-westrural-environment-and-agricultural-development-annual-report.pdf (accessed on 6 May 2020).

12. Mahadea, D. Delivering a Better Quality of Life for All in South Africa: Can SME Entrepreneurship Make a Difference? In Proceedings from ICSB 2014 World Conference; Dublin Institute of Technology: Dublin, Ireland, 2015; pp. 646-648. Available online: https:/ /icsb.org/wp-content/uploads/2017/07/ICSB2014_CD_Proceedings.pdf (accessed on 6 May 2020).

13. DAFF. Female Entrepreneur Awards Speech Delivered by the Honourable (ms) Tina Joemat-Pettersson, mp Minister of Agriculture, Forestry and Fisheries. 2013. Available online: https:/ / www.daff.gov.za/docs/speeches/FEMALE\%20ENTREPRENEUR\%20 AWARDS\%20SPEECH\%20BY\%20THE\%20MINISTER.pdf (accessed on 20 September 2020).

14. Mandipaka, F. Overview of women entrepreneurs in south Africa. Mediterr. J. Soc. Sci. 2014, 5, 127.

15. Gumede, V. Poverty and "Second Economy" in South Africa: An Attempt to Clarify Applicable Concepts and Quantify Extent of Relevant Challenges. SSRN Electron. J 2011. Available online: https:/ / papers.ssrn.com/sol3/papers.cfm?abstract_id=1360771 (accessed on 10 April 2020).

16. Mahlako, M. The Role of Women in Rural Development: The Case of the Molopo District of the North West Province. Master's Thesis, Rand Afrikaans University, Johannesburg, South Africa, 1996.

17. Witbooi, M.; Ukpere, W. Indigenous female entrepreneurship: Analytical study on access to finance for women entrepreneurs in South Africa. Afr. J. Bus. Manag. 2011, 5, 5646-5657.

18. Bauer, L. The COVID-19 Crisis Has Already Left Too Many Children Hungry in America. 2020. Available online: https://www. brookings.edu/blog/up-front/2020/05/06/the-COVID-19-crisis-has-already-left-too-many-children-hungry-in-america / (accessed on 19 June 2021).

19. Thurik, R.; Wennekers, S. Entrepreneurship, small business and economic growth. J. Small Bus. Enterp. Dev. 2004, 11, 140-149. [CrossRef]

20. Misango, S.B.; Ongiti, O.K. Do women entrepreneurs play a role in reducing poverty? A case in Kenya. Int. Rev. Manag. Bus. Res. 2013, 2, 87

21. Fiseha, G.G.; Oyelana, A.A. An Assessment of the Roles of Small and Medium Enterprises (SMEs) in the Local Economic Development (LED) in South Africa. J. Econ. 2015, 6, 280-290. [CrossRef]

22. Kim, J.C.; Watts, C.H.; Hargreaves, J.R.; Ndhlovu, L.X.; Phetla, G.; Morison, L.A.; Busza, J.; Porter, J.D.H.; Pronyk, P. Understanding the impact of a microfinance-based intervention on women's empowerment and the reduction of intimate partner violence in South Africa. Am. J. Public Health 2007, 97, 1794-1802. [CrossRef]

23. Vigoda, E. Organizational Politics, Job Attitudes, and Work Outcomes: Exploration and Implications for the Public Sector. J. Vocat. Behav. 2000, 57, 326-347. [CrossRef]

24. Holzmann, R.; Jørgensen, S. Social risk management: A new conceptual framework for social protection, and beyond. Int. Tax Public Financ. 2001, 8, 529-556. [CrossRef]

25. Agbenyegah, A.T. A Comparative Study of Rural Entrepreneurial Challenges: Towards Rural Economic Development and a Policy Framework. J. Econ. Behav. Stud. 2019, 11, 58-71. [CrossRef]

26. Luiz, J.; Mariotti, M. Entrepreneurship in an emerging and culturally diverse economy: A South African survey of perceptions. S. Afr. J. Econ. Manag. Sci. 2011, 14, 47-65. [CrossRef]

27. Nyamwanza, T.; Mapetere, D.; Mavhiki, S.; Dzingirai, C. Financial Management: Case Study of Gweru Women Entrepreneurs. Int. J. Bus. Soc. Sci. 2012, 3, 18. 
28. Akhalwaya, A.; Havenga, W. The Barriers That Hinder the Success of Women Entrepreneurs in Gauteng, South Africa. OIDA Int. J. Sustain. Dev. 2012, 3, 11-28.

29. Chinomona, E.; Maziriri, E.T. Women in Action: Challenges Facing Women Entrepreneurs in The Gauteng Province Of South Africa. Int. Bus. Econ. Res. J. 2015, 14, 835-850. [CrossRef]

30. Schumpeter, J.A. Can Capitalism Survive? Martino Fine Books: Eastford, CT, USA, 2020; pp. 298-315. Available online: https: / / schumpeter.info/schriften/Can\%20Capitalism\%20(1936).pdf (accessed on 19 June 2021).

31. Smitri, C. Innovation Theory of Trade Cycle: By J.A. Schumpeter 2015. Available online: https://www.yourarticlelibrary.com/ business/innovation-theory-of-trade-cycle-by-j-a-schumpeter/25996 (accessed on 17 August 2020).

32. relivingmbadays. Importance of Entrepreneurship in Developing Country. 2013. Available online: https://relivingmbadays. wordpress.com/2013/04/07/importance-of-entrepreneurship-in-developing-country/ (accessed on 3 May 2020).

33. Bates, T. Entrepreneur Human Capital Inputs and Small Business Longevity. Rev. Econ. Stat. 1990, 72, 551-559. [CrossRef]

34. Food and Agriculture Organization (FAO). The State of Food and Agriculture-Executive Summary; Food and Agriculture Organization: Rome, Italy, 2013; Available online: https:/ / www.fao.org/3/i3300e/i3300e00.htm (accessed on 22 September 2020).

35. Daud, S.A.; Omotayo, A.O.; Aremu, A.O.; Omotoso, A.B. Rural infrastructure and profitability of food crop production in oyo state, Nigeria. Appl. Ecol. Environ. Res. 2018, 16, 4655-4665. [CrossRef]

36. Ijatuyi, E. Assessment of Extension and Advisory Services on Nguni Cattle Development Project Beneficiaries in North West Province. Master's Thesis, North-West University, Mafikeng, South Africa, 2016. Unpublished.

37. Ijatuyi, E.J.; Omotayo, A.O.; Nkonki-Mandleni, B. Empirical analysis of food security status of agricultural households in the platinum province of South Africa. J. Agribus. Rural Dev. 2018, 47, 29-38. [CrossRef]

38. Omotayo, A.O. Parametric assessment of household's food intake, agricultural practices and health in rural South West, Nigeria Heliyon 2020, 6, e05433. [CrossRef]

39. Ijatuyi, E. Effects of Award Incentives and Competition on Entrepreneurship Development among Female Farmers in North West Province. Ph.D. Thesis, North-West University, Mafikeng Campus, Mafikeng, South Africa, 2020.

40. Shemfe, O.A.; Oladele, O.I. Extension officers' perception towards accreditation and regulation of extension services in North West Province, South Africa. S. Afr. J. Agric. Ext. 2018, 46, 44-58. [CrossRef]

41. Omotayo, A.O.; Aremu, A.O. Evaluation of factors influencing the inclusion of indigenous plants for food security among rural households in the North West Province of South Africa. Sustainability 2020, 12, 9562. [CrossRef]

42. Henning, S.; Akoob, K. Motivational factors affecting informal women entrepreneurs in North-West Province. S. Afr. J. Entrep. Small Bus. Manag. 2017, 9, 1-10. [CrossRef]

43. Ogunkoya, F.T. Socio-Economic Factors That Affect Livestock Numbers: A Case Study of Smallholder Cattle and Sheep Farmers in the Free State Province of South Africa. Master's Thesis, University of South Africa, Johannesburg, South Africa, 2014.

44. Phatudi-Mphahlele, M.G. Analysis of socio-economic impact of comprehensive agricultural support programme on agrarian reform farmers of sedibeng district municipality in Gauteng Province South Africa. Asia-Pac. Dev. J. 2016, 60, 1-26.

45. Spens, T. Studies on Agricultural Extension Involving Women, Including a Suggested Framework for the Analysis of Gender Issues in Agricultural Extension Programmes; UNIFEM: New York, NY, USA, 1986; Volume 3, p. 27.

46. Department of Agriculture, Forestry and Fisheries (DAFF). Abstract of Agricultural Statistics; 2013. Available online: https: / / www.nda.agric.za/docs/statsinfo/abstact2013.pdf (accessed on 10 September 2020).

47. Rachelson, D. Entrepreneurship News South Africa. 2017. Available online: https://www.bizcommunity.com/Article/196/626/ 166936.html (accessed on 17 October 2020).

48. Seyoum, C.; Lemma, T. Factors Determining the Degree of Commercialization of Smallholder Agriculture: The Case of Potato Growers in Kombolcha District, East Hararghe, Ethiopia. Journal of Agriculture and Development. 2011, 2, 18-36.

49. Naidoo, S.; London, L.; Rother, H.A.; Burdorf, A.; Naidoo, R.N.; Kromhout, H. Pesticide safety training and practices in women working in small-scale agriculture in South Africa. Occup. Environ. Med. 2010, 67, 823-828. [CrossRef] [PubMed]

50. FAO. Agriculture: Cause and Victim of Water Pollution, but Change Is Possible; Food and Agriculture Organization United States: Rome, Italy, 2019; Available online: https://www.fao.org/land-water/news-archive/news-detail/en/c/1032702/ (accessed on 4 April 2021).

51. FAO. Training Manual for Bookkeeping, Financial \& Management; 2013. Available online: https://www.fao.org/3/aq077e/aq0 77e00.pdf (accessed on 15 May 2021).

52. Oyewole, M.F. Welfare status of rural women agro-processors' participants in the development partnership in higher education project in Osun and Oyo States, Nigeria. J. Agric. Ext. 2017, 21, 39-46. [CrossRef]

53. Moloi, M. A Comparison of Socioeconomic Characteristics That Determine the Farm Income of Emerging Livestock and Horticultural Farmers in South Africa. Master's Thesis, University of Limpopo, Limpopo, South Africa, 2008.

54. Nwafor, C.U. Prospects of Commercialisation among Small Scale Potato Farmers in Bizana. Master's Thesis, Central University of Technology, Bloemfontein, South Africa, 2015.

55. Omotayo, A.O.; Ogunniyi, A.I.; Tchereni, B.H.; Nkonki-Mandleni, B. Understanding the link between households' poverty and food security in South West Nigeria. J. Dev. Areas 2018, 52, 27-38. [CrossRef]

56. Chengcai, T.; Linsheng, Z.; Shengkui, C. Tibetan Attitudes Towards Community Participation and Ecotourism. J. Resour. Ecol. 2012, 3, 8-15. [CrossRef] 
57. Spio, K. The Impact and Accessibility of Agricultural Credit: A Case Study of Small-Scale Farmers in Northern Province of South Africa. Ph.D. Thesis, University of Pretoria, Pretoria; South Africa, 2006.

58. Bremer, J.; Bhuiyan, S.H. Community-led infrastructure development in informal areas in urban Egypt: A case study. Habitat Int. 2014, 44, 258-267. [CrossRef]

59. Ijatuyi, E.J.; Omotayo, A.O.; Mabe, L.K. Effect of extension service(s) and socio-economic characteristics on the livelihood of Nguni cattle development project beneficiaries in North West Province: A tobit-ols regression approach. S. Afr. J. Agric. Ext. 2017, $45,64-77$.

60. Ndoro, J.T.; Mudhara, M.; Chimonyo, M. Cattle Commercialization in Rural South Africa: Livelihood Drivers and Implications for Livestock Marketing Extension. J. Hum. Ecol. 2014, 45, 207-221. [CrossRef]

61. Rootman, G.T.; Stevens, J.B.; Mollel, N.M. Policy Opportunities to Enhance the Role of Smallholder. S. Afr. J. Agric. Ext. 2015, 43, 91-104.

62. Ndoro, J. Cattle production, commercialization and marketing in smallholder farming systems of South Africa: Impacts and implications of livestock extension and market transaction costs. Ph.D. Thesis, University of KwaZulu-Natal, Durban, South Africa, 2015.

63. Alene, A.D.; Manyong, V.M.; Omanya, G.O.; Mignouna, H.D.; Bokanga, M.; Odhiambo, G.D. Economic Efficiency and Supply Response of Women as Farm Managers: Comparative Evidence from Western Kenya. World Dev. 2008, 36, 1247-1260. [CrossRef]

64. Greyling, J. The Role of the Agricultural Sector in the South African Economy. Master's Thesis, Stenllenbosch University, Stenllenbosch, South Africa, 2012.

65. Omotayo, A.O. Economic synergy between rural off-farm income and households' poverty in Ekiti State, Nigeria. J. Hum. Ecol. 2016, 56, 99-106. [CrossRef]

66. Adebayo, O.; Salman, K.K.; Omotayo, A.O.; Oluseyi, O.K. Welfare Impact of Remittances in South-West Nigeria: Rural and Urban Households Compared. J. Dev. Areas 2021. [CrossRef]

67. Ganiyu, M.O.; Omotayo, A.O. Effects of livelihood activities on the households' food security in the Ogbomoso South Local Government Area of Oyo State, Nigeria. J. Hum. Ecol. 2016, 56, 107-113. [CrossRef]

68. Omotayo, A.O.; Oyekale, A.S. Effect of malaria on farming households' welfare in Ido local government area of Oyo state, Nigeria. J. Hum. Ecol. 2013, 44, 189-194. [CrossRef] 